Abstracta Iranica Abstracta Iranica

Revue bibliographique pour le domaine irano-aryen

Volume 30 | 2010

Comptes rendus des publications de 2007

\title{
Le siècle d'Ispahan. Paris, Gallimard, 2007, 127 p., ill. en noir et en coul., cartes (Collection Découvertes - Histoire)
}

Eloïse Brac de La Perrière

\section{(2) OpenEdition}

Journals

Édition électronique

URL : http://journals.openedition.org/abstractairanica/37847

DOI : 10.4000/abstractairanica.37847

ISSN : 1961-960X

Éditeur :

CNRS (UMR 7528 Mondes iraniens et indiens), Éditions de l'IFRI

Édition imprimée

Date de publication : 8 avril 2010

ISSN : 0240-8910

Référence électronique

Eloïse Brac de La Perrière, «Le siècle d'Ispahan. Paris, Gallimard, 2007, 127 p., ill. en noir et en coul., cartes (Collection Découvertes - Histoire) », Abstracta Iranica [En ligne], Volume 30 | 2010, document 184, mis en ligne le 08 avril 2010, consulté le 10 octobre 2020. URL : http://journals.openedition.org/ abstractairanica/37847 ; DOI : https://doi.org/10.4000/abstractairanica.37847

Ce document a été généré automatiquement le 10 octobre 2020.

Tous droits réservés 
Le siècle d'Ispahan. Paris, Gallimard, 2007, 127 p., ill. en noir et en coul., cartes (Collection Découvertes Histoire)

Eloïse Brac de La Perrière 
Ce petit ouvrage de $127 \mathrm{p}$. est divisé en quatre chapitres auxquels succède, comme toujours dans cette collection, une série de documents historiques et littéraires, témoignages divers sur la période étudiée permettant au lecteur non-spécialiste de mieux en cerner les enjeux. Construit pour mettre en lumière les principales problématiques en lien avec le sujet, le texte de F.R. s'attache à expliquer, chronologiquement, ce que fut le siècle d'Ispahan, c'est-à-dire le XVII ${ }^{\mathrm{e}}$ s. où l'Iran bascula dans l'histoire pré-moderne, s'unifiant et centralisant le pouvoir autours de la dynastie des Safavides (1501-1732), tout particulièrement sous le règne éclairé du souverain Šāh 'Abbās I I (1588-1629). Ainsi, le premier chapitre revient sur la naissance de la dynastie et son essor sous Šāh Esmā‘īl I ${ }^{\text {er }}$ (1501-1524) et Šāh Ṭahmāsp I ${ }^{\text {er }}$ (1524-1576), alors que le deuxième chapitre est consacré à l'avènement de Šāh 'Abbās au tournant du siècle, sa politique internationale et son rôle primordial dans la création d'un réseau de communication qui favorisa l'essor économique et le développement de certaines productions artistiques. Ce n'est qu'au troisième et avant-dernier chapitre que le texte aborde le transfert de la capitale de Qazvin à Ispahan en 1598, mettant en avant l'importance de cette dernière, qui connut alors une envolée urbanistique, et son rôle centrale dans le commerce international, ainsi que la part des communautés arméniennes déportées dans cette révolution économique. Le dernier chapitre fait figure de conclusion, décrivant les dernières décennies d'un empire affaibli jusqu'à la chute de sa capitale en 1722. Comme l'ensemble des ouvrages de cette collection, le livre est richement illustré et la bibliographie, bien que fort succincte, comporte les principales références sur le sujet.

\section{INDEX}

Thèmes : 5.1. Monde iranophone

\section{AUTEURS}

\section{ELOÏSE BRAC DE LA PERRIÈRE}

Université Paris IV - Paris 